Ekspansi: Jurnal Ekonomi, Keuangan, Perbankan dan Akuntansi

ISSN (Online): 2580-7668 ISSN (Print): 2085-5230

Vol. 13, No. 1 (Mei 2021), Hal. 46 - 66

\title{
ANALISIS SEKTOR INDUSTRI PENGOLAHA DITINJAU DARI PENYERAPAN TENAGA KERJA: Di Kabupaten Bogor
}

\author{
Fakhrudin $^{1}$, Ade Jamal ${ }^{2}$ \\ ${ }^{1,2}$ Program Studi Manajemen Keuangan Mikro, IAI Tazkia, Bogor, Indonesia \\ Email Korespondensi: fakhrudin@tazkia.ac.id
}

\begin{abstract}
The purpose of this study is to examine whether the manufacturing sector, especially the large and medium scale sectors, is a basic sector or not in the Bogor Regency area in terms of the aspect of expanding employment opportunities. The quantitative methods used in this study are (1) Location Quotient (LQ) analysis, (2) labor surplus analysis, (3) multiplier coefficient, (4) specialization quotient, (5) localization quotient. The result shows that the manufacturing sector is the basic sector based on income indicators. However, this sector is not a basic sector based on labor indicators. This shows that the manufacturing sector plays less of a role in expanding employment than other sectors. However, several manufacturing industry sub-sectors are basic sub-sectors. These sub-sectors are the food, beverage and tobacco sub-sector, the textile, apparel and leather sub-sector, the wood, bamboo, rattan, grass and similar sub-sectors including household furniture, paper, paper goods, printing and publishing sub-sectors of chemicals and goods from chemical, petroleum, coal, rubber and non-metallic minerals sub-sectors.
\end{abstract}

Keywords: LQ; base sector; industrial sector

Abstrak: Tujuan penelitian ini adalah mengkaji apakah sektor industri pengolahan terutama yang berskala besar dan sedang merupakan sektor basis atau bukan basis di wilayah Kabupaten Bogor ditinjau dari aspek perluasan lapangan pekerjaaan. Metode kuantitatif yang digunakan dalam penelitian ini adalah (1) Analisis Location Quotient (LQ), (2) Analisis surplus tenaga kerja, (3) Koefisien pengganda, (4) Kuosien spesialisasi, (5) Kuosien lokalisasi. Hasilnya menunjukan sektor industri pengolahan merupakan sektor basis berdasarkan indikator pendapatan. Namun, sektor tersebut bukan merupakan sektor basis berdasarkan indikator tenaga kerja. Hal tersebut menunjukkan bahwa sektor industri pengolahan kurang berperan dalam perluasan lapangan pekejaan dibanding sektor lainnya. Tetapi,beberapa subsektor industri pengolahan merupakan subsektor basis. Subsektor-subsektor tersebut adalah subsektor makanan, minuman dan tembakau, subsektor tekstil, pakaian jadi dan kulit, subsektor kayu, bambu, rotan, rumput dan sejenisnya termasuk perabot rumah tangga, subsektor kertas, barang dari kertas, percetakan dan penerbitan subsektor kimia dan barang dari kimia, minyak bumi, batubara, karet dan subsektor barang galian bukan logam.

Kata Kunci: LQ; sektor basis; sektor industri 


\section{PENDAHULUAN}

Pembangunan di sektor industri pengolahan mempunyai peranan yang sangat penting dalam pembangunan perekonomian suatu wilayah. Peranannya terlihat dari keterkaitan yang erat antara pembangunan sektor industri pengolahan dengan pembangunan sektor pertanian, jasa, peningkatan pendapatan, serta perluasan lapangan kerja.

Pembangunan sektor industri pengolahan tentu saja harus diarahkan untuk meningkatkan pendapatan masyarakat secara keseluruhan, tetapi juga memperluas lapangan kerja. Sehingga pembangunan sektor industri pengolahan akan mampu menekan tingkat pengangguran dan masalah kemiskinan.

Bagi daerah Kabupaten Bogor, sektor industri pengolahan dalam PDRB (Produk Domestik Regional Bruto) memberikan kontribusi terbesar dibandingkan dengan sektor-sektor lainnya. Besaran kontribusi sektor industri pengolahan dapat dilihat dalam Tabel 1.

Dari Tabel 1. dapat dilihat bahwa pada tahun 2015 sektor industri pengolahan menyumbang sebesar 49,30\%, sedangkan pada tahun 2016 kontribusinya turun sebesar 48,0\%, kontribusinya meningkat pada tahun 2002 menjadi 49,21\%. Kontribusi sektor industri dari aspek pendapatan jauh mengungguli sektor-sektor lainnya.

Sebagaimana digambarkan di atas sektor industri merupakan sektor yang paling dominan dalam kontribusinya terhadap PDRB Kabupaten Bogor. Kontribusi tersebut disumbangkan oleh tiga jenis industri pengolahan yaitu industri besar, sedang, serta industri kecil. Industri besar adalah industri yang mempunyai jumlah tenaga kerja berjumlah lebih dari 100 orang, sedangkan, indusri sedang adalah industri yang mencakup perusahaan industri dengan jumlah tenaga kerja 20 orang lebih. Sedangkan industri kecil 5 sampai 19 orang dan industri rumah tangga 1 sampai 4 orang.

\section{Tabel 1. Distribusi Persentase PDRB Kabupaten Bogor Atas Dasar Harga Konstan Menurut Lapangan Usaha Tahun 2015-2017}

\begin{tabular}{|c|c|c|c|c|}
\hline No & Uraian & 2015 & 2016 & 2017 \\
\hline 1. & Pertanian & 12,20 & 10,39 & 11,45 \\
\hline 2. & Pertambangan dan Penggalian & 1,62 & 1,61 & 1,55 \\
\hline 3. & Industri Pengolahan & 49,30 & 48,50 & 49,21 \\
\hline 4. & Listrik, Gas dan Air Minum & 3,21 & 3,71 & 3,66 \\
\hline 5. & Bangunan & 5,09 & 5,19 & 5,29 \\
\hline 6. & Perdagangan, Hotel dan Restoran & 15,27 & 15,25 & 15,20 \\
\hline 7. & Pengangkutan dan Komunikasi & 4,27 & 4,40 & 4,46 \\
\hline 8. & $\begin{array}{l}\text { Keuangan, Persewaan, dan Jasa } \\
\text { Perusahaan }\end{array}$ & 2,50 & 2,68 & 2,69 \\
\hline 9. & Jasa-jasa Lainnya & 6,51 & 6,51 & 6,49 \\
\hline \multicolumn{2}{|l|}{ Jun } & 100,00 & 100,00 & 100,00 \\
\hline
\end{tabular}

Sumber: Kantor Statistik Kabupaten Bogor,

Ditinjau dari intensitas penggunaan faktor produksinya dapat dikelompokkan menjadi dua macam. Pertama, industri yang berorientasi pada pada modal. Kedua, 
industri yang berorientasi pada padat karya. Kedua macam industri tersebut memiliki kelebihan dan kekurangan masing-masing.

Industri yang berorientasi pada padat modal cenderung akan memberikan kontribusi pendapatan yang relatif besar. Sedangkan industri yang beorientasi pada padat karya akan cenderung menciptakan lapangan kerja yang lebih luas.

Pada dasarnya pengembangan sektor industri pengolahan memiliki potensi dalam penyerapan tenaga kerja serta memperluas lapangan pekerjaan. Selain membutuhkan tenaga kerja relatif lebih banyak sektor ini mempunyai keterkaitan erat dengan sektor lainnya. Oleh karena itu, perlu diupayakan pengembangan pada sektor industri pengolahan, khususnya berkaitan dengan upaya dalam memperluas lapangan pekerjaan.

Pengembangan sektor industri pengolahan skala besar dan sedang harus dikaitkan dengan sumberdaya sekitar dan potensi wilayah masing-masing, karena selain lebih efisien juga akan memberikan dampak langsung pada wilayah yang bersangkutan. Dengan penggunaan sumberdaya dan memperhatikan potensi wilayah masing-masing diharapkan akan terbentuk keunggulan komparatif pada masing-masing industri yang akan mendorong terjadinya perdagangan antar wilayah yang paling menguntungkan. Salah satu pendekatan yang digunakan untuk pengembangan sektor tersebut adalah analisis sektor basis.

Dengan model pengembangan tersebut sektor industri pengolahan akan lebih mendorong tercapainya tujuan pembanguanan wilayah yang berupa peningkatan pendapatan dan penekanan tingkat pengangguran.

Penelitian ini bertujuan: pertama, melihat apakah sektor industri pengolahan dan subsektor industri pengolahan merupakan kegiatan basis di Kabupaten Bogor. Kedua, Mengidentifikasikan subsektor basis industri pengolahan pada setiap kecamatan di Kabupten Bogor. Ketiga, mengetahui tingkat spesialisasi dan lokalisasi subsektor basis industri pengolahan pada setiap kecamatan di Kabupaten Bogor. Keempat, mengkaji peranan sektor industri pengolahan terhadap kesempatan kerja.

\section{TINJAUAN PUSTAKA \\ Teori Basis Ekonomi}

Dalam konteks ilmu ekonomi regional, terdapat berbagai teori yang menjelaskan sektor-sektor dalam perekonomian regional atau perubahan-perubahan kondisi perekonomian di suatu daerah. Salah satu konsep yang dapat digunakan untuk menganalisa pertumbuhan regional adalah teori basis ekonomi (economic base theory).

Hanafiah (1989) membagi kegiatan dalam suatu wilayah menjadi kegiatan basis dan kegiatan bukan basis. Kegiatan basis merupakan kegiatan suatu masyarakat yang hasilnya dapat berupa barang dan jasa yang ditujukan untuk diekspor keluar dari lingkungan masyarakat tersebut. Jadi dapat digolongkan kepada kegiatan masyarakat yang berorientasi ke luar, regional, nasional dan internasional. Konsep efisiensi teknis maupun efisiensi ekonomis sangat menentukan pertumbuhan kegiatan basis suatu wilayah, dalam pengertian persaingan dan prinsip perbandingan keuntungan. 
Kegiatan bukan basis merupakan kegiatan masyarakat yang hasilnya, baik berupa barang dan jasa, diperuntukan bagi masyarakat itu sendiri dalam kawasan kehidupan ekonomi masyarakat tersebut. Barang-barang jadi dan pelayanan diperuntukan bagi ruang lingkup kesejahteraan dan pasar mereka sendiri. Konsep swasembada, mandiri, kesejahteraaan dan kualitas hidup sangat menentukan kegiatan bukan basis ini.

Menurut Hoover (1977) kegiatan basis merupakan kegiatan yang pertumbuhannya akan mendorong dan menentukan pola pembangunan daerah secara keseluruhan, sedangkan kegiatan bukan basis merupakan kegiatan yang perkembangannya hanya merupakan akibat dari adanya pembangunan daerah secara keseluruhan. Disamping itu, ekonomi basis dapat dipergunakan untuk: (1) mengidentifikasikan kegiatan daerah yang bersifat ekspor, (2) meramal pertumbuhan yang mungkin terjadi dalam aktivitas basis, (3) mengevaluasi pengaruh kegiatan ekspor tambahan terhadap kegiatan bukan basis. Hasil tersebut bukan saja merupakan sebuah proyeksi dari prospek pertumbuhan daerah yang diharapkan dan perubahan struktural, tetapi juga merupakan suatu model yang dapat digunakan untuk mengevaluasi pengaruh dari kecendrungan alternatif pertumbuhan ekspor.

Teori basis ekonomi menganalisis perubahan dalam suatu wilayah yang diakibatkan oleh ekspor pada kondisi statis dalam jangka pendek (short run), sedangkan penerapan dalam kondisi dinamis dalam jangka panjang dapat dijelaskan dengan teori basis ekspor yang dikemukakan oleh Nort dalam Glasson (1977). Menurut teori ini pertumbuhan suatu daerah ditentukan oleh eksploitasi sumberdaya alam dan pertumbuhan basis akspor yang sangat dipengaruhi oleh permintaan eksternal dari wilayah lain (external demand). North juga menganalisa timbulnya perkembangan di suatu wilayah dan perkembangan selanjutnya dari wilayah tersebut terutama diakibatkan oleh bertambah baiknya kedudukan ekspor pada pasar di luar wilayah, dan kemampuanya untuk bersaing dengan ekspor yang sama atau sejenis dari wilayah yang lain.

Menurut Kadariah (1985), kegiatan basis akan menghasilkan barang dan jasa untuk pasar lokal maupun untuk pasar di luar daerah tersebut. Sedangkan kegiatan bukan basis sangat dipengaruhi oleh kenaikan pendapatan daerah, akibat adanya kegiatan basis dan hasilnya diperuntukkan bagi masyarakat itu sendiri.

Untuk mengetahui sektor basis atau bukan basis dapat dipergunakan beberapa metode. Richardson (1977) mengemukakan bahwa untuk menentukan kegiatan basis atau bukan basis dengan menggunakan metode pengukuran langsung dan metode pengukuran tidak langsung.

Metode pengukuran langsung dapat dilakukan melalui survai langsung untuk mengetahui sektor mana yang merupakan sektor basis. Metode ini dapat menentukan sektor basis dengan tepat. Akan tetapi metode ini memerlukan biaya, waktu, dan tenaga kerja yang banyak. Sehingga sebagian besar pakar ekonomi wilayah menggunakan metode pengukuran tidak langsung, yaitu:

a. Metode Arbiter, dilakukan dengan cara membagi secara langsung kegiatan perekonomian ke dalam kategori ekspor dan non ekspor tanpa melakukan penelitian secara spesifik di tingkat lokal. Metode ini memperhatikan kenyatan 
bahwa kegiatan ekonomi bisa terdapat kegiatan ekonomi yang akan menghasilkan barang yang sedang di ekspor dan sebagian dijual secara lokal ataupun keduaduanya.

b. Metode location quotient (LQ), merupakan suatu alat analisa untuk melihat atau membandingkan peranan suatu sektor tertentu dalam suatu wilayah dengan peranan sektor tersebut dalam wilayah yang lebih luas.

c. Metode Kebutuhan minimum, merupakan modifikasi dari metode LQ dan metode ini sangat tergantung pada pemilihan persentase minimum dan tingkat disagregasi yang terlalu terperinci dapat mengakibatkan hampir semua sektor menjadi kegiatan basis untuk diekspor.

Dari ketiga metode tersebut, Glasson (1977) menyarankan metode LQ untuk menentukan sektor basis. Richardson (1977) mengemukakan bahwa teknik LQ adalah teknik yang paling layak digunakan dalam studi basis empirik. Asumsinya adalah bahwa suatu wilayah lebih spesialisasi dalam memproduksi barang tertentu, maka wilayah tersebut akan mengekspor barang sesuai dengan tingkat spesialisasinya.

Menurut Kadariah (1984), metode pendekatan LQ merupakan teknik analisa yang tergolong sederhana dalam menentukan atau memilih kegiatan ekonomi yang akan dikembangkan di suatu wilayah atau akan menentukan lokasi bagi suatu kegiatan ekonomi. Metode LQ digunakan untuk mengukur kegiatan di suatu wilayah dengan jalan membandingkan peranannya dalam perekonomian secara keseluruhan.

Asumsi yang digunakan adalah jumlah penduduk di setiap daerah mempunyai pola permintaan yang sama dengan pola permintaan daerah yang lebih luas, produktivitas tenaga kerja sama, pada setiap industri menghasilkan barang yang homogen. Selain itu, permintaan wilayah akan suatu barang pertama-tama akan dipenuhi oleh hasil produksi wilayah itu sendiri. Jika jumlah yang diminta melebihi jumlah produksi wilayah, barulah kekuranganya akan diimpor. Sebaliknya, produksi yang dihasilkan terlebih dahulu ditunjukan untuk konsumsi lokal dan diekspor keluar wilayah yang berasal dari surplus produksi.

Konsep basis ekonomi sangat baik digunakan, karena sangat sederhana dan mudah diterapkan. Teori basis ekonomi ini tetap relevan dalam menganalisa stuktur perekonomian, dapat memberikan peramalan pertumbuhan suatu wilayah serta dampak yang diakibatkan oleh perubahan-perubahan dalam jangka pendek.

Dalam pengunaan konsep basis ekonomi juga terdapat banyak kekurangan kekurangan yang meliputi: (a) perubahan untuk lokasi harus disesuaikan dengan penentuan kegiatan basis atau bukan basis, (b) perubahan arus pemasukan modal, seperti investasi pemerintah pusat yang dapat mengurangi peranan dari sektor basis, (c) kebocoran wilayah berupa tabungan dan pajak yang dapat mengurangi peranan sektor basis, (d) pertumbuhan suatu wilayah yang dapat terjadi bukan karena pengaruh ekspor (kegiatan basis), tetapi terjadi juga karena investasi secara besar-besaran yang dilakukan oleh pemerintah pusat, migrasi, subtitusi impor dan. peningkatan efisiensi suplai lokal, (e) konsep basis tidak dapat menjelaskan tingkat keseimbangan pertumbuhan antar wilayah dan hubungan antar tingkat pendapatan dan kapasitas ekspor. 
Menurut Glasson (1977), dalam penggunaan teori basis ekonomi terdapat kelemahan, antara lain kekurangan yang bersifat teknis, seperti unit pengukuran, metode identifikasi, pemilihan unit wilayah serta diabaikannya peranan impor. Kadirah (1985) mengemukakan pula kelemahan teori basis ekonomi, yaitu sering terjadinya pelanggaran terhadap asumsi yang digunakan, antara lain : (1) selera dan pola pengeluaran atau pola konsumsi masyarakat yang berbeda di tiap daerah, (2) tingkat konsumsi rata-rata, untuk masing-masing barang tidak sama di setiap wilayah, (3) kebutuhan sarana produsi untuk proses produksi dan produktivitas tenaga kerja di setiap wilayah berbeda

\section{Lokasi Kegiatan Industri Pengolahan}

Produksi memerlukan pengunaan faktor-faktor produksi untuk menghasilkan output dari barang dan jasa seefisien mungkin. Lokasi dari unit produksi atau perusahaan sudah barang tentu berhubungan denga input dan pasar bagi output. Dengan demikian faktor-faktor produksi yang beraneka ragam, seperti tanah, modal dan faktor produksi pasar menjadi penentu primer dari lokasi. Faktor-faktor tersebut tentu saja dapat dirinci menjadi penentu yang lebih spesifik, seperti kualitas dan kuantitas tenaga kerja, lokasi geografi dan ketersediaan prasarana yang akan diperlukan.

Pengetahuan tentang lokasi kegiatan sektor industri pengolahan memegang peranan yang sangat penting dalam menyusun rencana pembangunan industri pengolahan, karena setiap wilayah memiliki faktor lokasi yang berbeda dalam menunjang pertumbuhan kegiatan industri pengolahannya. Perbedaan tersebut menyebabkan setiap wilayah memiliki perbedaan potensi untuk mengembangkan komoditas industri pengolahan tertentu.

Faktor-faktor yang perlu diperhatikan temasuk kegiatan ekonomi industri pengolahan menurut Djojodipuro (1992) adalah sebagai berikut:

a. Faktor endowment

Faktor ini menunjukan adanya ketersediaan faktor-faktor produksi secara kualitas maupun kuantitas pada daerah tertentu. Faktor tesebut meliputi modal, tenaga kerja dan kesuburan tanah. Semakin banyak faktor endowment maka semakin banyak pula pertimbangan untuk menentukan lokasi kegiatan industri pengolahan.

b. Pasar dan harga

Tujuan dari kegiatan industri pengolahan adalah untuk menjual hasil pengolahan dengan harga yang lebih tinggi daripada biaya yang dikeluarkan. Dalam hal ini luasan pasar memegang peranan penting dalam meningkatkan nilai penjualan para pengusaha yang menekuni bidang ini. Harga yang berlaku di pasar didasarkan pada harga produksi dan kondisi permintaan para konsumen.

c.. Ketersediaan saran produksi

Lokasi industri pengolahan dan penjualan dari sarana produksi perlu diperhatikan untuk menjamin ketersediaan sarana, produksi seperti adanya bahan baku, peralatan produksi, fasilitas telekomunikasi, fasilitas transportasi dan sebagainya. Ketersediaan saran produksi tersebut dapat menunjang kesinambungan kegiatan industri 
pengolahan komersial. Selain itu, lokasi industri pengolahan yang berdekatan dengan penjual sarana produksi akan mengurangi biaya pengangkutan.

d. Biaya angkutan

Menurunkan biaya angkutan, merupakan salah satu masalah pokok untuk mendapatkan keuntungan optimal. Kondisi jalan dan jenis angkutan memegang peranan penting untuk mengangkut hasil dari suatu industri pengolahan ke pasar, memberangkatkan konsumen dan mengangkut sarana produksi.

e. Kebijakan pemerintah

Pemerintah sebagai penentu kebijakan mempunyai kekuasaan atau wewenang dan dapat mempengaruhi penentuan lokasi untuk berbagai kegiatan ekonomi melalui kebijaksanaan per wilayahan dan lokasi. Kebijaksanaan tersebut didasarkan pada kesejahteraan masyarakat yang secara georafis terbesar dalam tata ruang.

Dalam perkembanganya, kegiatan industri pengolahan akan berorientasi pada pasar (konsumen) apabila terjadi penyebaran sumberdaya dan faktor produksi yang merata, serta biaya transportasi yang relatif murah. Orientasi pasar ini akan menunjukan bahwa setiap lokasi akan dapat menghasilkan komoditi industri pengolahan tertentu, tetapi suatu kegiatan industri pengolahan akan dapat bekembang pada lokasi tertentu karena adanya kemudahan bagi konsumen potensial yang berasal dari dalam atau dari luar lokasi untuk datang ke lokasi pemasaran komoditi industri pengolahan tersebut.

Kegiatan industri pengolahan akan berorientasi lokal, apabila terjadi penyebaran faktor produksi dan sumberdaya, tetapi biaya transportasi relatif mahal. Orientasi lokal ini artinya suatu lokasi akan menghasilkan suatu komoditi tertentu untuk memenuhi kebutuhan setempat, karena adanya biaya transportasi yang relatif besar apabila dibandingkan dengan keuntungan yang diperolehnya.

Suatu lokasi akan berorientasi pada sumberdaya, apabila sumberdaya alam tidak merata, sedangkan biaya trasportasi relatif murah dan faktor produksi yang menyebar. Artinya walaupun faktor produksi tersedia dan biaya transportasi relatif murah, suatu kegiatan industi pengolahan pada lokasi tertentu akan berhasil dengan baik karena sumberdaya atau bahan baku pada wilayah tersebut atau pada wilayah lain terdekat cocok untuk kegiatan. tersebut.

\section{METODE PENELITIAN}

\section{Jenis Data dan Sumber Data}

Data yang digunakan adalah data sekunder yang diperoleh dari Biro Pusat Statistik (BPS) yang berupa data dalam angka di daerah penelitian. Data tersebut meliputi data nilai tambah dan jumlah tenaga kerja sektor industri pengolahan di Kabupaten Bogor dan Propinsi Jawa Barat, serta data jumlah tenaga kerja subsektor industri pengolahan untuk Kabupaten Bogor dan Kecamatan-kecamatan di Kabupaten Bogor.

\section{Location Quotient (LQ)}

Penggunaan Location Quotients (kuosien lokasi) bertujuan untuk mengetahui apakah sektor x merupakan kegiatan basis atau kegiatan bukan basis. Sektor x yang dimaksud dalam penelitian ini adalah sektor industri pengolahan. 
Metode pendekatan $L Q$ merupakan perbandingan antara pendapatan relatif suatu sektor tertentu dalam suatu wilayah dengan total pendapatan relatif sektor tertentu dalam suatu wilayah yang lebih luas, secara matematis dirumuskan sebagai berikut (Richardson dalam Budiharsono, S. 1989):

$$
L Q=\frac{V_{i} / V_{t}}{v_{i} / v_{t}}
$$

dimana :

LQ = besarnya kuosien lokasi

$\mathrm{Vi} \quad=$ jumlah pendapatan / tenaga kerja sektor industri pengolahan di Kabupaten Bogor

$\mathrm{Vt} \quad=$ jumlah pendapatan / tenaga kerja total di Kabupaten Bogor

vi = jumlah pendapatan / tenaga kerja sektor industri pengolahan di Propinsi Jawa Barat

vt $\quad=$ jumlah pendapatan / tenaga kerja total di Propinsi Jawa Barat

Kriteria penilaian dari hasil perhitungan di atas adalah: jika hasil perhitungan $L Q$ $>1$ sektor atau subsektor tersebut berarti sektor basis atau subsektor basis. Tetapi apabila didapat $L Q<1$, maka sektor atau subsektor tersebut bukan basis.

\section{Analisis Surplus Pendapatan dan Tenaga Kerja}

Analisis ini merupakan besaran yang digunakan untuk mengukur secara langsung jumlah surplus pendapatan/tenaga kerja yang terjadi dengan menghitung perbedaan antara pendapatan / tenaga kerja sektor tertentu di suatu wilayah dengan pendapatan / tenaga kerja sektor tertentu di dalam wilayah yang lebih luas kemudian dikalikan dengan jumlah pendapatan/ tenaga kerja sektor tertentu di dalam wilayah (Santoso,H.1987). Rumus umum surplus pendapatan/tenaga kerja adalah :

$$
\begin{aligned}
& \text { Sij }=\text { Sei }^{*} Y_{j} \\
& \text { Sij }=(\text { Ryj }- \text { Ryt }){ }^{*} Y t
\end{aligned}
$$

Dimana:

$\mathrm{Sij} \quad=$ surplus pendapatan atau tenaga kerja

Ryj $\quad=$ peranan sektor industri di Kabupaten Bogor

Ryt = peranan sektor industri pengolahan, Provinsi Jawa Barat

$\mathrm{Yj}=$ total tenaga kerja di Kabupaten Bogor

Sei $\quad=$ indeks surplus

Jika hasil perhitungan didapat $\mathrm{Sij}>0$ berarti kegiatan sektor industri pengolahan di Kabupaten Bogor mampu memenuhi kebutuhan sendiri serta mampu untuk memenuhi kebutuhan di wilayah luar. Apabila $\mathrm{Sij}<0$ berarti kabupaten tesebut akan 
mengimpor dari luar Kabupaten Bogor dan berorientasi pada pemakaian tenaga kerja di dalam wilayah tersebut.

\section{Koefisien Pengganda (multiflier effect)}

Koefisien pengganda pendapatan menunjukan besarnya efek peningkatan pendapatan atau tenaga kerja dari kegiatan sektor basis di suatu wilayah terhadap tambahan pendapatan kegiatan sektor non basis di wilayah yang sama atau tehadap perekonomian wilayah secara keseluruhan.

Tiebout (1962) dalam Santoso, H. (1987) mengatakan, jika porsi pendaptan sektor basis yang di belanjakan kembali di dalam suatu wilayah adalah sebesar $r$, maka total pendapatan sektor basis yang dibelanjakan adalah sebesar $\mathrm{Yb}+(\mathrm{r}) \mathrm{Yb}$. Kemudian dilakukan pembelanjaan kembali, sehingga total pendapatan yang diperoleh adalah sebesar $\mathrm{Yb}+(\mathrm{r}) \mathrm{Yb}+\left(\mathrm{r}^{2}\right) \mathrm{Yb}$ dan seterusnya. Keadaan tersebut dapat dirumuskan sebagai berikut :

$$
\begin{aligned}
\mathrm{Y} & =\mathrm{Yb}+(\mathrm{r}) \mathrm{Yb}+\left(\mathrm{r}^{2}\right) \mathrm{Yb}+\ldots+\left(\mathrm{r}^{\mathrm{n})} \mathrm{Yb}\right. \\
& =\left(1+\mathrm{r}^{+} \mathrm{r}^{+} \mathrm{r}^{\prime}+\ldots+\mathrm{r}^{\mathrm{n}}\right) \mathrm{Yb}
\end{aligned}
$$

Rumus tersebut dapat disederhanakan menjadi:

$$
\begin{aligned}
\mathrm{Y} & =\mathrm{Yb}[1 / 1-\mathrm{r}] \quad \text { atau } \\
r & =\frac{Y-Y b}{(\Phi)}
\end{aligned}
$$

Karena demikian koefisien efek pengganda adalah

$$
\begin{aligned}
Q= & \frac{1}{1-r}=\frac{1}{1-(Y n / Y)}=\frac{1}{(Y-Y n) / Y} \\
Q= & \frac{1}{1-r} \\
& \text { dimana: }
\end{aligned}
$$

$$
\begin{aligned}
& \mathrm{Yn} \quad \text { pendapatan atau tenaga kerja sektor non basis } \\
& \mathrm{Yb} \quad \text { e } \quad \text { jumlah pendapatan atau tenaga kerja basis } \\
& \mathrm{Y}=\text { jumlah total pendapatan atau tenaga kerja wilayah } \\
& \mathrm{R}=\quad \text { porsi pendaptan sektor basis yang di belanjakan kembali } \\
& \mathrm{n}=\quad \text { banyaknya pembelajaan }
\end{aligned}
$$

\section{Kuosien Spesialisasi}

Analisis ini digunakan untuk mengetahui spesialisasi suatu daerah pada suatu kegiatan sehingga diketahui keunggulan komparatif (Warpani, 1984). Kuosien spesialisasi merupakan selisih antara jumlah pendapatan atau tenaga

kerja seluruh sektor tertentu terhadap jumlah pendapatan atau tenaga kerja seluruh sektor dalam suatu wilayah dengan jumlah pendaptan sektor yang sama dalam 
wilayah luas terhadap total pendapatan seluruh sektor di wilayah yang lebih luas (Kartono,H.1986). Dengan demikian kuosien spesialisasi dapat dirumuskan:

$$
\mathrm{Ksi} \quad=(\mathrm{Si} / \mathrm{S})-(\mathrm{Ni} / \mathrm{N})
$$

dimana:

$\mathrm{Si} \quad=$ jumlah tenaga kerja subsektor i pada tingkat kecamatan

$\mathrm{S}=$ jumlah total tenaga kerja subsektor industri pengolahan pada tingkat kabupaten

$\mathrm{Ni}=$ jumlah tenaga kerja subsektor i pada tingkat kabupaten

$\mathrm{N}=$ jumlah total tenaga kerja subsektor industri pengolahan pada tingkat kabupaten

$\mathrm{KS}=$ kuosien spesialisasi dengan menjumlahkan nilai KS yang positif

Jika dari hasil perhitungan didapat $\mathrm{KS}=1$, maka suatu daerah berspesialisasi pada kegiatan tertentu dan jika KS $<1$, maka tidak ada kegiatan spesialisasi di suatu daerah.

\section{Kuosien Lokalisasi}

Analisis ini digunakan untuk mengetahui penyebaran kegiatan industri pengolahan di suatu daerah, sehingga diketahui tingkat aglomerasi yang merupakan selisih antara jumlah pendapatan suatu sektor dalam wilayah terhadap pendapatan seluruh sektor dalam suatu wilayah terhadap total pendapatan seluruh sektor di wilayah yang lebih luas (Kartono,H. 1986). Dengan demikian kuosien lokalisasi dapat dirumuskan sebagai berikut:

$$
\mathrm{Loi}=(\mathrm{Si} / \mathrm{Ni})-(\mathrm{S} / \mathrm{N})
$$

dimana:

$\mathrm{Si}=$ jumlah tenaga kerja subsektor i pada tingkat kecamatan

$\mathrm{S}=$ jumlah total tenaga kerja subsektor industri pengolahan pada tingkat kecamatan

$\mathrm{Ni}=$ jumlah tenaga kerja subsektor i pada tingkat kabupaten

$\mathrm{N}=$ jumlah total tenaga kerja subsektor industri pengolahan pada tingkat kabupaten

Lo = kuosien lokalisasi dengan cara menjumlahkan, jika Loi $<1$ maka lokalisasi menyebar, Loi $=1$ berarti lokalisasi kegiatan memusat.

\section{HASIL DAN PEMBAHASAN}

\section{Analisis Basis Industri Pengolahan}

Pembahasan mengenai basis industri pengolahan dilakukan dengan cara menghitung nilai Location Quotien (LQ). Dalam pembahasan ini tahap awalnya menggunakan indikator tenaga kerja (employment) dan pendapatan wilayah (PDRB).

Sebelum dilakukan analisis Location Quotient (LQ) untuk subsektor industri, terlebih dahulu dilakukan perhitungan nilai LQ untuk masing-masing sektor perekonomian di Kabupaten Bogor dengan wilayah Propinsi Jawa Barat sebagai wilayah pembanding. Penjabaran secara luas sektor-sektor perekonomian dapat 
membantu pemerintah daerah untuk menentukan sektor unggulan yang diprioritaskan dan dikembangkan dalam pembangunan daerah selanjutnya. Nilai LQ sektor-sektor ekonomi tersebut dapat dilihat pada Tabel 2.

\section{Tabel 2. Nilai $L Q$ Sektor-Sektor Produksi di Kabupaten Bogor Berdasarkan Indikator Pendapatan Tahun 2017}

\begin{tabular}{|l|l|l|}
\hline No & Sektor & Nilai \\
\hline 1. & Pertanian & 0.814 \\
\hline 2. & Pertambangan & 0.308 \\
\hline 3. & Industri Pengolahan & 1.288 \\
\hline 4. & Listrik. Gas dan Air Minum & 1.609 \\
\hline 5. & Bangunan & 1.469 \\
\hline 6. & Perdagangan & 0.689 \\
\hline 7. & Pengangkutan & 0.831 \\
\hline 8. & Keuangan & 0.672 \\
\hline 9. & Jasa & 0.839 \\
\hline
\end{tabular}

Sektor basis adalah sektor yang mempunyai nilai LQ lebih besar atau sama dengan satu, artinya sektor tersebut telah mampu memenuhi kebutuhan sektor tersebut di daerahnya dan mempunyai potensi untuk mengekspor ke luar daerah. Sebaliknya jika nilai LQ-nya lebih kecil dari satu, berarti sektor yang bersangkutan termasuk sektor non basis dan hares mengimpor dari luar daerah untuk memenuhi kebutuhan akan sektor tersebut.

Berdasarkan perhitungan nilai LQ di seluruh sektor ekonomi di Kabupaten Bogor, terdapat tiga sektor ekonomi yang menjadi sektor basis berdasarkan indikator pendapatan, yaitu sektor industri pengolahan, listrik, gas, air minum dan bangunan. Hal ini menunjukan sektor telah mampu memenuhi permintaan wilayah dan akan mendorong pertumbuhan wilayah tersebut.

Selain berdasarkan indikator pendapatan wilayah, nilai LQ juga dapat dilihat dengan menggunakan indikator tenaga kerja. Berikut ini nilai LQ untuk masingmasing sektor ekonomi di Kabupaten Bogor dengan menggunakan indikator tenaga kerja dengan wilayah Jawa Barat sebagai wilayah pembanding.

Tabel 3. Nilai LQ Sektor-Sektor Produksi di Kabupaten Bogor Berdasarkan Indikator Tenaga Kerja Tahun 2017

\begin{tabular}{|l|l|l|}
\hline No & Sektor & Nilai LQ \\
\hline 1. & Pertanian & 0.906 \\
\hline 2. & Pertambangan & 2.321 \\
\hline 3. & Industri Pengolahan & 0.698 \\
\hline 4. & Listrik. Gas dan Air & 1.159 \\
\hline 5. & Bangunan & 1.218 \\
\hline 6. & Perdagangan & 1.126 \\
\hline 7. & Pengangkutan & 1.324 \\
\hline 8. & Keuangan & 1.311 \\
\hline 9. & Jasa & 1,165 \\
\hline
\end{tabular}


Berdasarkan hasil perhitungan di atas, terdapat tujuh sektor ekonomi yang menjadi sektor basis di Kabupaten Bogor berdasarkan indikator tenaga kerja, yaitu sektor pertambangan, listrik, gas dan air minum, bangunan, perdagangan, pengangkutan, keuangan dan jasa. sedangkan untuk sektor industri pengolahan tidak menjadi sektor basis.

Sedangkan untuk sektor industri pengolahan di wilayah Kabupaten Bogor tidak menjadi sektor basis berdasarkan indikator tenaga kerja. Hal tersebut menunjukan sektor industri pengolahan lebih cenderung bersifat padat modal dibandingkan dengan sektor industri pengolahan pada wilayah Jawa Barat. Jadi peran sektor industri pengolahan dalam menyerap tenaga kerja sangat kurang.

Analisis $L Q$ subsektor industri pengolahan berdasarkan indikator tenaga kerja

Nilai LQ sektor industri pengolahan dan subsektor industri pengolahan berdasarkan indikator tenaga kerja dapat dilihat pada Tabel 4. Suatu wilayah dikatakan memiliki basis ekonomi sektor $\mathrm{x}$ jika nilai $L Q$ sektor tersebut bernilai satu atau lebih dari satu. Sedangkan sektor $\mathrm{x}$ di wilayah i dikatakan bukan basis ekonomi, jika nilai LQ bernilai lebih kecil dari satu.

Tabel 4. Nilai LQ Subsektor Industri Pengolahan Berdasarkan Indikator Tenaga Kerja di Kabupaten Bogor Tahun 2017

\begin{tabular}{|l|l|l|l|}
\hline No & Subsektor & LQ & B/NB \\
\hline 1. & Industri Pengolahan & 0,698 & NB \\
\hline 2. & Makanan, minuman \& tembakau & 1,193 & $\mathrm{~B}$ \\
\hline 3. & Tekstil, pakaian jadi \& kulit & 1,306 & $\mathrm{~B}$ \\
\hline 4. & $\begin{array}{l}\text { Kayu, bambu, rotan, rumput } \\
\text { sejenisnya }\end{array}$ & 6,062 & $\mathrm{~B}$ \\
\hline 5. & $\begin{array}{l}\text { Kertas,barang dari kertas, percetakan } \\
\text { dan penerbitan }\end{array}$ & 2,911 & $\mathrm{~B}$ \\
\hline 6. & $\begin{array}{l}\text { Kimia \& barang dari kimia, minyak } \\
\text { bumi, batubara, karet }\end{array}$ & 1,733 & $\mathrm{~B}$ \\
\hline 7. & Barang galian bukan logam & 3,457 & $\mathrm{~B}$ \\
\hline 8. & Logam dasar & 0.716 & $\mathrm{NB}$ \\
\hline 9. & Barang dari logam dan peralatannya & 0,982 & $\mathrm{NB}$ \\
\hline
\end{tabular}

Keterangan: $\mathrm{B}$ artinya basis dan NB artinya sektor non basis

Hasil analisis pada Tabel 4. Terdapat 7 sub sektor yang merupakan sektor basis, hal tersebut ditunjukan oleh nilai $L Q$ sub sektor tersebut lebih dari 1 . Sub sektor industri kayu, bambu, rotan, rumput dan sejenisnya termasuk perabotan rumah tangga memiliki nilai $L Q$ yang tertinggi diantara semua subsektor, yakni 6,0616. Hal tersebut disebabkan kontribusi terhadap penyerapan tenaga kerja di Kabupaten Bogor relatif lebih besar dibanding penyerapan tenaga kerja pada sub sektor tersebut di Jawa Barat.

\section{Analisis Location Quotient Subsektor Industri Pengolahan di Kecamatan}

Sebelum mengetahui tingkat spesialisasi dan lokalisasinya sektor industri pengolahan di kabupaten dan kecamatan, terlebih dahulu diketahui subsektor basis 
industri pengolahan di setiap kecamatan. Hal tersebut untuk memudahkan pemahaman gejala yang terjadi pada analisis kuosien spesialisasi dan kuosien lokalisasi.

Nilai $L Q$ pada bagian ini di peroleh dari perbandingan antara jumlah tenaga kerja relatif subsektor industri pengolahan tertentu pada tingkat kecamatan $(\mathrm{Si} / \mathrm{S})$ dengan total tenaga kerja relatif tertentu pada tingkat kabupten $(\mathrm{Ni} / \mathrm{N})$. suatu subsektor dikatakan atau tergolong subsektor basis apabila nilai LQ lebih dari satu, sedangkan nilai $L Q$ yang kurang dari satu berarti subsektor yang dihasilkan bukan subsektor basis.

Hasil perhitungan LQ berdasarkan indikator tenaga kerja pada Tabel 5 . menunjukan bahwa hanya beberapa kecamatan yang memiliki subsektor basis. Subsektor tersebut mempunyai nilai LQ lebih dari satu, sehingga tergolong sebagai subsektor basis industri pengolahan .

Pada tabel 5. terlihat hanya beberapa kecamatan yang mempunyai subsektor basis industri pengolahan, diantaranya adalah Nanggung, Ciawi, Cisarua, Sukaraja, Cileungsi, Gunung Putri, Citeureup, Cibinong dan Bojonggede. Kecamatankecamatan tersebut memiliki jumlah subsektor basis yang berbeda-beda. Kecamatan yang memiliki jumlah subsektor basis yang ter banyak adalah kecamatan Cileungsi dan Gunung putri dengan Sembilan subsektor basis, kemudian kecamatan Citeureup dengan tujuh subsektor basis serta Cibinong dengan empat subsektor basis.

Memang kecamatan-kecamatan yang memiliki subsektor basis yang terbanyak merupakan kecamatan-kecamatan yang memiliki industri skala besar dan sedang di semua subsektor serta kedudukannya berada pada daerah Bogor yang berdekatan dengan Kota Bogor dan jaraknya tidak jauh dari Ibu Kota Jakarta.

\section{Kuosien Spesialisasi Subsektor Industri Pengolahan}

Analisis Kuosien Spesialisasi (KS) merupakan analisis untuk mengetahui spesialisasi suatu kegiatan industri pengolahan di suatu daerah sehingga diketahui keunggulan komparatif. Analisis kuosien spesialisasi pada subsektor industri pengolahan bertujuan untuk mengetahui ada tidaknya spesialisasi suatu kegiatan pada subsektor basis industri pengolahan .

Nilai kuosien spesialisasi (KS) diperoleh dari selisih antara nilai relatif peranan subsektor industri pengolahan tertentu di wilayah kabupaten $(\mathrm{Si} / \mathrm{S})$ dengan nilai relatif peranan subsektor di wilayah propinsi dan juga selisih antara nilai relatif peranan subsektor industri pengolahan tertentu di wilayah kecamatan $(\mathrm{Si} / \mathrm{S})$ dengan nilai relatif subsektor industri pengolahan tersebut di wilayah Kabupaten Bogor. Apabila nilai KS lebih kecil dari satu maka kegiatan industri pengolahan berskala besar dan sedang di wilayah kabupaten dan kecamatan cenderung beragam tidak memfokuskan pada satu kelompok atau dapat dikatakan tidak ada kegiatan spesialisasi. Sedangkan apabila nilai KS sama dengan satu atau mendekati satu maka ada spesialisasi kegiatan industri pengolahan baik pada wilayah kecamatan maupun wilayah kabupaten.

Pada Tabel 6. menunjukkan kuosien spesialisasi untuk sektor industri pengolahan di Kabupaten Bogor bemilai positif dan kurang dari satu, artinya tidak ada spesialisasi kegiatan industri pengolahan dan kegiatannya sangat beragam. Sedangkan hanya 
beberapa kecamatan yang memiliki nilai kuosien spesialisasi, hal tersebut dikarenakan hanya beberapa kecamatan yang memiliki subsektor industri pengolahan.

Adapun nilai kuosien spesialisasi semuanya bemilai kurang dari satu artinya bahwa tidak ada kegiatan spesialisasi subsektor industri pengolahan. Hal tersebut disebabkan karena subsektor basis industri pengolahan pada kecamatan tertentu juga merupakan subsektor basis pada kecamatan lainnya. misalnya Kecamatan Nanggung memiliki industri makanan dan minuman ternyata juga dimiliki oleh kecamatan Ciampea dan kecamatan yang lainnya. Selain itu pada tabel terlihat nilai kuosien spesialisasi yang dimiliki setiap kecamatan nilainya kurang dari 0,5 sehingga tingkat spesialisasi subsektor basis industri pengolahan relatif kecil untuk dapat dikatakan sebagai komoditi spesialisasi bagi kecamatan tertentu.

\section{Kuosien Lokalisasi Kegiatan Sektor Industri pengolahan}

Nilai kuosien lokalisasi (KL) ini diperoleh dengan menghitung selisih antara rasio tenaga kerja subsektor industri pengolahan tertentu di wilayah kecamatan dan kabupaten Bogor $(\mathrm{Si} / \mathrm{Ni})$ dengan rasio total tenaga kerja subsektor industri pengolahan tersebut di wilayah kecamatan dan tabupaten Bogor $(\mathrm{S} / \mathrm{N})$, kemudian KL yang nilainya positif yang dimiliki subsektor tersebut dijumlahkan. Apabila nilai KL yang kurang dari satu berarti lokasi kegiatan industri pengolahan tersebut menyebar, sedangkan apabila nilai KL sama dengan satu berarti lokasi kegiatan tersebut memusat dan semakin besar nilai KL berarti kegiatan industri pengolahan semakin memusat.

Tabel 5. Subsektor Basis Industri Pengolahan di Kecamatan Kabupaten Bogor Tahun 2017

\begin{tabular}{|l|l|l|}
\hline No & Kecamatan & Subsektor \\
\hline 1. & Nanggung & Makanan, minuman,tembakau \\
\hline 2. & Leuwiliang & - \\
\hline 3. & Pamijahan & - \\
\hline 4. & Cibungbulang & - \\
\hline 5. & Ciampea & - \\
\hline 6. & Dramaga & - \\
\hline 7. & Ciomas & - \\
\hline 8. & Tamansari & - \\
\hline 9. & Cijeruk & - \\
\hline 10. & Caringin & - \\
\hline 11. & Ciawi & $\begin{array}{l}\text { Makanan, minuman,tembakau, kimia \& barang dari bahan kimia } \\
\text { industri } \\
\text { pengolahan lainnya }\end{array}$ \\
\hline 12. & Cisarua & Makanan,minuman, tembakau \\
\hline 13. & Megamendung & - \\
\hline 14. & Sukaraja & Kertas, barang dari kertas, percetakan,penerbitan \\
\hline 15. & Babakan Madang & - \\
\hline 16. & Sukamakmur & - \\
\hline 17. & Cariu & - \\
\hline 18. & Jonggol & - \\
\hline
\end{tabular}




\begin{tabular}{|c|c|c|}
\hline No & Kecamatan & Subsektor \\
\hline 19. & Cileungsi & $\begin{array}{l}\text { Makanan,minuman, tembakau, tekstil, pakaian jadi, kulit, kayu, } \\
\text { bambu, rotan, rumput, perabot rumah tangga, kertas barang dari } \\
\text { kertas, percetakan, penerbitan,kimiAbarang dari kimia, minyak bumi, }\end{array}$ \\
\hline 20. & Klapanunggal & \\
\hline 21. & Gunung Putri & $\begin{array}{l}\text { Makanan,minuman, tembakau, tekstil, pakaian jadi, kulit, kayu, } \\
\text { bambu, rotan, rumput, perabot rumah tangga, kertas barang dari } \\
\text { kertas, percetakan, penerbitan,kimia\&barang dari kimia, minyak }\end{array}$ \\
\hline 22. & Citeureup & $\begin{array}{l}\text { Makanan,minuman, tembakau, tekstil, pakaian jadi, kulit, kayu, } \\
\text { bambu, rotan, rumput, perabot rumah tangga,kimia \& barang dari }\end{array}$ \\
\hline 23. & Cibinong & makanan, minuman, tembakau, tekstil, pakaian jadi,kulit, kayu, \\
\hline 24. & Bojonggede & - \\
\hline 25. & Kemang & 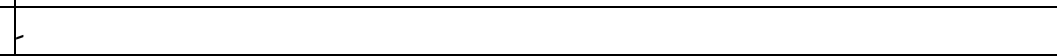 \\
\hline 26. & Rancabungur & - \\
\hline 27. & Parung & - \\
\hline 28. & Ciseeng & - \\
\hline 29. & Gunung Sindur & - \\
\hline 30. & Rumpin & 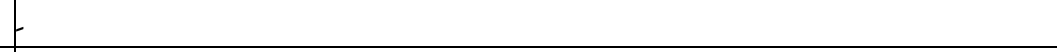 \\
\hline 31. & Cigudeg & - \\
\hline 32. & Sukajaya & 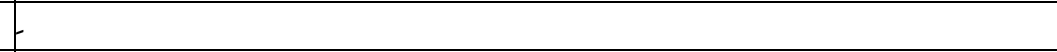 \\
\hline 33. & Jasinga & - \\
\hline 34. & Tenjo & - \\
\hline 35. & Parung Panjang & 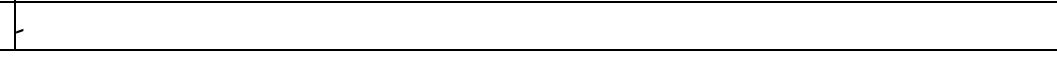 \\
\hline
\end{tabular}

Tabel 6. Kuosien Spesialisasi kegiatan Industri dan Subsektor Industri Pengolahan di Kabupaten Bogor dan kecamatannva Tahun 2017

\begin{tabular}{|l|l|c|l|l|c|}
\hline No & $\begin{array}{l}\text { Kabupaten dan } \\
\text { Kecamatan }\end{array}$ & KS & $\begin{array}{l}\text { Kabupaten dan } \\
\text { Kecamatan }\end{array}$ & KS \\
\hline 1. & Bogor & 0,03767 & 19 & Jonggol & 0 \\
\hline 2. & Nanggung & 0,0062 & 20 & Cilengsi & 0,2849 \\
\hline 3. & Leuwiliang & 0 & 21 & Klapanunggal & 0 \\
\hline 4. & Pamijahan & 0 & 22 & Gunung Putri & 0,1451 \\
\hline 5. & Cibungbulang & 0 & 23 & Citereup & 0,1652 \\
\hline 6. & Ciampea & 0 & 24 & Cibinong & 0,1688 \\
\hline 7. & Dramaga & 0,1685 & 25 & Bojonggeda & 0 \\
\hline 8. & Ciomas & 0 & 26 & Kemang & 0 \\
\hline 9. & Tamansari & 0 & 27 & Rancabungur & 0 \\
\hline 10. & Cijeruk & 0 & 28 & Parung & 0 \\
\hline 11. & Caringin & 0 & 29 & Ciseeng & 0 \\
\hline 12. & Ciawi & 0,0319 & 30 & Gunung Sindur & 0 \\
\hline 13. & Cisarua & 0,0111 & 31 & Rumpin & 0 \\
\hline 14. & Megamendung & 0 & 32 & Cigudeg & 0 \\
\hline 15. & Sukaraja & 0,0131 & 33 & Sukajaya & 0 \\
\hline 16. & Babakan Madang & 0 & 34 & Jasinga & 0 \\
\hline
\end{tabular}




\begin{tabular}{|l|l|c|c|l|c|}
\hline No & $\begin{array}{l}\text { Kabupaten dan } \\
\text { Kecamatan }\end{array}$ & KS & No & $\begin{array}{l}\text { Kabupaten dan } \\
\text { Kecamatan }\end{array}$ & KS \\
\hline 17. & Sukamakmur & 0 & 35 & Tenjo & 0 \\
\hline 18. & Cariu & 0 & 36 & Parung Panjang & 0 \\
\hline
\end{tabular}

Sumber : Tabel Lampiran 7

Hasil analisis kuosien lokalisasi pada Tabel 7. menunjukan bahwa semua subsektor industri pengolahan di Kabupaten Bogor menyebar. Tingkat lokalisasi subsektor basis tersebut di Kabupaten Bogor nilainya kurang dari satu.

Hasil analisis menunjukan bahwa hampir semua subsektor industri pengolahan lokalisasinya menyebar dalam wilayah Kabupaten Bogor. Hal ini terlihat dari nilai kuosien lokalisasi subsektor industri pengolahan berkisar antara 0,2 sampai dengan 0,9 .

Subsektor yang mempunyai tingkat lokalisasi tertinggi adalah subsektor barang galian bukan logam kecuali minyak bumi dan batubara yaitu 0,8949 dan subsektor logam dasar sebesar 0,7713 yang berarti subsektor tersebut lebih memusat di suatu wilayah di Kabupaten Bogor. Wilayah-wilayah tersebut antara lain Kecamatan Cileungsi, Kecamatan Gunung Putri dan Kecamatan Citeureup.

Analisis kuosien lokalisasi hanya dapat memberikan suatu gambaran secara umum tentang potensi kegiatan industri pengolahan berskala besar dan sedang di suatu kecamatan tertentu. Sehingga penentuan lokalisasi bila dilihat dari aspek teknis, sosial dan ekonomi belum dapat dijadikan pegangan dalam pelaksanaan pembangunan sektor industri pengolahan. Namun hasil analisis tersebut dapat dijadikan informasi awal bagi perencanaan pembangunan wilayah.

\section{Peranan Sektor Industri pengolahan dalam Peningkatan Lapangan Pekerjaan}

Berdasarkan indikator tenaga kerja sektor industri pengolahan ternyata bukan merupakan kegiatan basis, tetapi beberapa subsektor industri pengolahan adalah basis. Jadi pembahasan mengenai peranan sektor industri pengolahan dilakukan dengan cara menghitung nilai surplus tenaga kerja dan efek pengganda didasarkan pada subsektor industri pengolahan.

Langkah pertama dalam menentukan analisis surplus tenaga kerja dan efek pengganda adalah mengklasifikasikan subsektor industri pengolahan yang merupakan kegiatan basis, khususnya dalam penelitian ini berdasarkan indikator tenaga kerja. Kemudian ditentukan indeks surplus tenaga kerjanya.

Tabel 7. Tingkat Lokalisasi Subsektor Basis Industri Pengolahan di Kabupaten Bogor Tahun 2017

\begin{tabular}{|l|ll|}
\hline No & Subsektor & LQ \\
\hline 1. & Makanan, minuman dan tembakau & 0,2995 \\
\hline 2. & Tekstil, pakaian iadi dan kulit & 0,5600 \\
\hline 3. & Kayu, bambu, rotan, rumput dan sejenisnya termasuk 0,6307 \\
\hline 4. & Kertas, barang dari kertas, percetakan dan penerbitan & 0,3063 \\
\hline 5. & Kimia dan barang dari bahan kimia, minvak bumi, batubara, & 0,5886 \\
\hline 6. & Barang galian bukan logam & 0,8949 \\
\hline 7. & Logam dasar & 0,7713 \\
\hline
\end{tabular}


No Subsektor LQ

8. Barang dari logam . mesin dan peralatannva 0.6429

9. Pengolahan lainnya 0,6268

Sumber : Tabel Lampiran 8

\section{Surplus Tenaga Kerja dan Efek Pengganda}

Analisis surplus tenaga kerja pada subsektor basis industri pengolahan pada Kabupten Bogor dalam periode 2002 diperoleh dari perkalian antara tenaga kerja sektor $\mathrm{x}$ dengan indeks surplusnya. Indeks surplus merupakan selisih antara kontribusi sektor $\mathrm{x}$ di wilayah Kabupaten Ciamis (Ryi) dengan kontribusi sektor di wilayah Jawa Barat (Ryj). Sektor tersebut terdiri dari subsektor makanan, minuman dan tembakau, subsektor tekstil, pakaian jadi dan kulit, subsektor kayu, bambu, rotan, rumput dan sejenisnya temasuk perabotan rumah tangga, subsektor kertas, barang dari kertas, percetakan dan penerbitan, subsektor kimia dan barang dari kimia, minyak bumi, batubara, karet dan plastik dan subsektor barang galian bulan logam kecuali minyak bumi dan batubara.

Tabel 8. Nilai Surplus Tenaga Kerja Subsektor Industri Pengolahan di Kabupaten Bogor Tahun 2017

\begin{tabular}{|l|l|l|l|l|}
\hline No & Subsektor & Isi & TKi & STki \\
\hline 1. & Makanan, minuman \& tembakau & 0,00122 & 157758 & 192,14 \\
\hline 2. & Tekstil, pakaian jadi \& kulit & 0,01214 & 157758 & 1915,20 \\
\hline 3. & $\begin{array}{l}\text { Kayu, bambu, rotan, rumput \& sejenisnya termasuk } \\
\text { perabotan rumah tangga }\end{array}$ & 0,00581 & 157758 & 916,49 \\
\hline 4. & Kertas, barang dari kertas, percetakan dan penerbitan & 0,00325 & 157758 & 511,94 \\
\hline 5. & $\begin{array}{l}\text { Kimia. \& barang dari kimia, minyak bumi, batubara, } \\
\text { karet }\end{array}$ & 0,00647 & 157758 & 1020,40 \\
\hline 6. & Barang galian bukan logam & 0,00919 & 157758 & 1449,00 \\
\hline
\end{tabular}

Keterangan:

Isi $\quad=$ indeks surplus tenaga kerja subsektor industri pengolahan

Tki = tenaga kerja total Kabupaten Bogor

STKi = surplus tenaga kerja sektor industri pengolahan

Analisis surplus tenaga kerja menggambarkan bahwa wilayah $\mathrm{x}$ sudah mampu mengekspor produk i atau perlu mengimpor. Konsep analisis surplus pendapatan ini berhubuangan erat dengan konsep analisis kuosien lokasi (LQ). Bila semua sektor dikatakan sebagai sektor basis berdasarkan indikator tenaga kerja maka sektor tersebut mempunyai surplus tenaga kerja. Sedangkan bila suatu sektor digolongkan sebagai sektor non basis, maka surplus tenaga kerjanya akan bernilai negatif. Nilai-nilai surplus tenaga kerja dari beberapa subsektor $\mathrm{x}$ di wilayah I dapat diihat pada Tabel 8 di atas.

Dari hasil perhitungan di atas, subsektor makanan, minuman dan tembakau, subsektor tekstil, pakaian jadi dan kulit; subsektor kayu, bambu, rotan, rumput dan sejenisnya temasuk perabotan rumah tangga; subsektor kertas, barang dari kertas, percetakan dan penerbitan; subsektor kimia dan barang dari kimia, minyak bumi, batubara, karet dan plastik dan subsektor

barang galian bukan logam kecuali minyak bumi dan batubara memiliki surplus tenaga kerja pada tahun 2017 bernilai positif Hal ini disebabkan sektor-sektor tersebut merupakan sektor basis ekonomi. Ini berarti subsektor tersebut di Kabupaten Bogor 
telah mampu memenuhi permintaan wilayah dan terdapat surplus untuk di ekspor. Hasil analisis surplus tenaga kerja ternyata mendukung hasil nalisis LQ pada subsektor basis industri pengolahan di Kabupaten Bogor.

Selanjutnya akan dibahas mengenai dampak sektor industri atau subsektor industri pengolahan terhadap perkembangan sektor lain menggunakan alat analisis multiplier effect (afek pengganda). Koefisien efek pengganda (mutiplier effect) sektor industri pengolahan berdasarkan indikator tenaga kerja merupakan perbandingan antara total tenaga kerja wilayah suatu daerah pada tahun tertentu dengan tenaga kerja sektor industri atau subsektor industri pada daerah dan tahun yang sama.

Tabel 9. Nilai Efek Pengganda Subsektor Indutri Pengolahan Bedasarkan Indikator Penyerapan Tenaga Kerja di Kabupaten Bogor Tahun 2017

\begin{tabular}{|l|l|l|l|l|}
\hline No & Subsektor & TK & Tki & MTK \\
\hline 1. & Makanan, minuman \& tembakau & 157758 & 9440 & 16,7117 \\
\hline 2. & Tekstil, pakaian jadi \& kulit \& sejenisnya termasuk & 157758 & 64929 & 2,4297 \\
\hline 3. & $\begin{array}{l}\text { Kayu, bambu,rotan,rumput \& } \\
\text { perabotan rumah tangga }\end{array}$ & 157758 & 8707 & 18,1185 \\
\hline 4. & Kertas,barat dari kertas, percetakan \& penerbitan & 157758 & 6187 & 25,4983 \\
\hline 5. & Kimia \& barang dari kimia, minyak bumi, batu bara karet. & 157758 & 19135 & 8,24447 \\
\hline 6. & Barang galian bukan logam & 157758 & 16173 & 9,75441 \\
\hline
\end{tabular}

Keterangan :

$\mathrm{TK}=$ total tenaga kerja Kabupaten Bogor

$\mathrm{TKi}=$ total tenaga kerja subsektor industri pengolahan

MTK = koefisien pengganda tenaga kerja

Nilai pengganda pada tabel tersebut menggambarkan dampak yang ditimbulkan oleh adanya perluasan tenaga kerja sektor industri pengolahan basis terhadap pertumbuhan tenaga kerja wilayah keseluruhan. Nilai koefisien pengganda tenaga kerja pada subsektor makanan, minuman, dan tembakau yaitu sebesar 16,7117, hal ini berarti peningkatan kesempatan kerja setiap satu orang di subsektor tersebut akan terjadi peningkatan kesempatan tenaga kerja sebanyak 17 orang (dibulatkan).

Sebaliknya apabila terjadi penurunan kesempatan tenaga kerja setiap 1 orang pada sektor tersebut maka akan menyebabkan pengangguran sebanyak 17 orang. Begitu pula halnya yang terjadi pada subsektor basis lainnya. Hasil perhitungan nilai pengganda pendapatan tersebut sebenarnya tidak dapat diterapkan secara mutlak, melainkan harus turut memperhatikan faktor-faktor lain yang mempengaruhinya. Dengan demikian nilai pengganda harus dipandang sebagai gambaran secara secara umum dampak perkembangan penyerapan tenaga kerja terhadap perkernbangan penyerapan tenaga kerja lain yang selanjutnya mempengaruhi tenaga kerja total.

\section{PENUTUP}

Berdasarkan tujuan dari penelitian ini maka kesimpulan yang diperoleh adalah:

1. Sektor industri pengolahan di Kabupaten Bogor merupakan sektor basis berdasarkan indikator pendapatan. Tetapi, sektor industri pengolahan merupakan sektor bukan basis berdasarkan indikator tenaga kerja. Hal tersebut menunjukan bahwa sektor industri pengolahan di wilayah Kabupaten Bogor 
lebih padat modal daripada sektor industri pengolahan di wilayah Propinsi Jawa Barat. Berdasarkan indikator tenaga kerja beberapa subsektor merupakan sektor basis seperti, subsektor makanan, minuman dan tembakau, subsektor tekstil, pakaian jadi dan kulit, subsektor kayu, bambu, rotan, rumput dan sejenisnya temasuk perabotan rumah tangga, subsektor kertas, barang dari kertas, percetakan dan penerbitan, subsektor kimia dan barang dari kimia, minyak bumi, batubara, karet dan plastik dan subsektor barang galian bukan logam kecuali minyak bumi dan batubara.

2. Untuk wilayah kecamatan di Kabupaten Bogor hanya beberapa kecamatan yang memiliki subsektor pengolahan meliputi Kecamatan Nanggung, Kecamatan Ciawi, Kecamatan Cisarua, Kecamatan Sukaraja, Kecamatan Cileungsi, Kecamatan Gunung Putri, Kecamatan Citeureup dan Kecamatan Cibinong. Dari kecamatan-kecamatan tersebut yang mempunyai subsektor terbanyak adalah Kecamatan Cileungsi, Kecamatan Gunung Putri dan Kecamatan Citereup yang terdiri dari 9 subsektor untuk Kecamatan Cileungsi dan kecamatan Gunung Putri dan 7 sektor untuk Kecamatan Citeureup.

3. Di Kabupaten Bogor tidak terjadi spesialisasi pada sektor industri pengolahan ini, hal tersebut dapat dilihat dari nilai kuosien spesialisasi pada wilayah Bogor kurang dari satu, yaitu sebesar 0,03767. Dan untuk wilayah kecamatan juga, tidak terjadi spesialisasi pada sektor pengolahan, hal tersebut terlihat dari nilai kuosien spesialisasi di masing-masing kecamatan kurang dari satu. Dengan membandingkan nilai kuosien spesialisasi di setiap kecamatan bahwa yang mempunyai nilai kuosien spesialisasi terbesar adalah kecamatan Cileungsi dengan nilai 0,2849. Dan tingkat penyebaran pada sektor pengolahan, ini tidak begitu menyebar, bahkan ada beberapa kecamatan yang tidak memiliki subsektor pengolahan, hal tersebut didukung oleh nilai kuosien lokalisasi pada setiap subsektor kurang dari satu. Berdasarkan perhitungan yang ada subsektor yang memiliki nilai kuosien spesialisasi terbesar adalah subsektor barang galian bukan logam dengan nilai 0.8949, memang subsektor tersebut hanya terdapat di beberapa kecamatan di Kabupaten Bogor. Kecamatan-kecamatan tersebut adalah Kecamatan Cileungsi, Kecamatan Gunung putri dan Kecamatan Citeureup. Subsektor lain yang mempunyai nilai kuosien lokalisasi di atas 0,5 adalah subsektor industri kayu, bambu, rotan, rumput dan sejenisnya termasuk pembantu rumah tangga, subsektor logam dasar, subsektor barang dari logam, mesin dan peralatannya dan subsektor pengolahan lainnya.

4. Peranan sektor industri pengolahan melalui basis subsektornya dalam pembangunan wilayah Kabupaten Bogor di dalam penyerapan tenaga kerja atau penciptaan lapangan pekerjaan cukup besar. Hal tersebut dapat dilihat dari nilai surplus tenaga kerja. Pada subsektor basis tersebut yang mempunyai nilai terbesar dalam penyerapan tenaga kerja adalah subsektor tekstil, pakaian jadi, kulit dan barang galian bukan logam. Dan efek pengganda yang terbesar dari sub sekor basis industri pengolahan adalah subsektor kertas, barang dari kertas, persetakan dan penerbitan subsektor kayu, bambu, rotan, rumput dan 
sejenisnya termasuk perabotan rumah tangga dan subsektor makanan, minuman dan tembakau. Berdasarkan nilai surplus tenaga kerja dan efek pengganda subsektor pengolahan yang paling potensial dibandingkan subsektor lainnya adalah subsektor kayu, bambu, rotan, rumput dan sejenisnya termasuk perabotan rumah tangga karena memiliki surplus tenaga kerja yang cukup besar juga termasuk subsektor yang mempunyai efek pengganda yang besar.

\section{Saran}

1. Kebijakan pengembangan sektor industri pengolahan dalam rangka memperluas lapangan pekerjaan di wilayah Kabupaten Bogor hendaknya memprioritaskan subsektor basis industri pengolahan, khususnya subsektor makanan, minuman dan tembakau pada lokasi yang potensial.

Perlu dilakukan penelitian lebih lanjut mengenai potensi wilayah industri pengolahan dan spesialisasi subsektor industri pengolahan. Disamping itu perlu penelitian sampai pada tingkat komoditas sektor industri dan penelitian di seluruh skala sektor industri pengolahan.

\section{DAFTAR PUSTAKA}

Arsyad, Lincoln. Pengantar Perencanaan dan Pembangunan Ekonomi Daerah. Yogyakarta :BPFE - UGM, 2006

Badan Pusat Statistik Kabupaten Bogor. Bogor Dalam Angka 2017. Bogor.

Badan Pusat Statistik Propinsi Jawa Barat. Jawa Barat Dalam Angka 2017. Bandung. Djojodipuro, M. Teori Lokasi. Jakarta: Lembaga Penerbit Fakultas Ekonomi Universitas Indonesia, 1992.

Glasson, Jhon. Pengantar Perencanaan. Jakarta: Lembaga Penerbit Fakultas Ekonomi Universitas Indonesia, 1977.

Hanafiah, T. Pendekatan Wilayah dan Pembangunan Pedesaan. Bogor: jurusan Sosial Ekonomi Pertanian IPB, 1988.

Kadirah. Ekonomi Perencanaan. Jakarta : Lembaga Penerbit Fakultas Ekonomi Universitas Indonesia, 1985.

Razak, Abdul "Analisis Basis Pertanian Dalam Rangka Pembangunan Wilayah" Institut Pertanian Bogor: Skripsi, 1994.

Richardson, H. Dasar-Dasar Ilmu Ekonomi Regional. Jakarta : Lembaga Penerbit Fakultas Ekonomi Universitas Indonesia, 1977.

Sugandhy, Aca " Penataan Ruang Wilayah Daerah dan Kota" Prisma. 1984. No. 6 Tahun XIII LP3ES.

Tanmella, Susianna " Peranan dan Dampak Sektor Pertanian Terhadap Pembangunan Wilayah" Institut Pertanian Bogor, 1999.

Todaro, Michael P. Ekonomi Pembangunan 1. Jakarta : Bumi Aksara, 2000.

Warpani, S. Analisis Kota dan Daerah. Bandung : Penerbit Institut Teknologi Bandung, 1984. 